\title{
Progression på tid og på tværs. Fremdrift og fleksibilisering som styringsregime på de videregående uddannelser
}

Laura Louise Sarauw, ph.d., postdoc, Institut for Uddannelse og Pædagogik, Aarhus Universitet.

\section{Reviewet artikel}

\begin{abstract}
Med den kommende studiefremdriftsreform følger både krav om hurtigere gennemførelse og en fleksibilisering af systemet, der skal lette meritoverførslen og gøre det nemmere at sammenstykke en uddannelse på tvars af institutioner og uddannelser. Artiklen diskuterer de nye tiltag som en bestemt styring af de studerendes uddannelsesnavigation: Hvad sker der, når vi giver den enkelte studerende storre frihed til at sammensætte uddannelse på tværs af moduler, der ikke har nogen på forhånd tilrettelagt (faglig) progression mellem sig? Vil den øgede valgfrihed medvirke til at motivere de studerende, højne gennemførelsen og gøre dem mere arbejdsmarkedsparate, sådan som regeringen fremlægger det? Og er prisen $i$ givet fald en fragmentering af viden og instrumentel overfladelæring blandt de studerende, sådan som kritikerne foreslår?
\end{abstract}

\section{Fremdrift og pro(re)gression i de videregående uddannelser}

Studiefremdriftsreformen, som omfatter alle nye studerende fra og med sommeren 2014, rummer for det første en reform af SU-systemet og rammerne for studiegennemførelse. Med det overordnede mål at accelerere de studerendes gennemførelseshastighed er universiteterne forpligtet til at nedbringe den gennemsnitlige studietid med 4,3 måneder i 2020. Fremover vil alle studerende derfor automatisk blive tilmeldt (nye) eksaminer af 60 ECTS-point om året. Desuden må de maksimalt være 6 måneder forsinket, før SU-udbetalingen stoppes (Folketinget, 2013).

For at sætte yderligere fut under fremdriften er der for det andet lagt op til en såkaldt fleksibilisering af hele det videregående uddannelsessystem. Målet er blandt andet at give bedre rammer for merit ved studieophold på anden institution eller studieskift samt etablere bedre overgange mellem bachelor- og kandidatuddannelser, så de studerende samlet set kommer hurtigere igennem (ibid.; se også Regeringen, 2012). Men fleksibiliseringen åbner på samme tid for, at en videregående uddannelse fremover vil kunne komponeres af en række separate enkeltdele, hvis indbyrdes sammenhæng vil bero på den enkelte studerende. 
Formålet med denne artikel er i den anledning at diskutere forskellige scenarier for, hvad den kombinerede fremdriftsorientering og fleksibiliserering kan få af betydning for de studerendes progression og uddannelsesnavigation: Hvordan forholder de to teknologier sig til hinanden? Hvad betyder det for de studerende, at reformen på den ene side giver incitament til færre fejl- og omvalg end tidligere, og på den anden side fremstår som et opgør med den i dag udbredte forestilling om en fra uddannelsens side intenderet (faglig) progression? Vil den øgede valgfrihed medvirke til at motivere de studerende, højne gennemførelsen og gøre dem mere arbejdsmarkedsparate sådan, som regeringen fremlægger det? Og er prisen da en fragmenteret og instrumentel overfladelæring blandt de studerende sådan, som kritikerne foreslår?

Da reformen i skrivende stund endnu ikke er trådt i kraft, er artiklens empiriske grundlag først og fremmest den aktuelle reformtekst (Folketinget, 2013) samt regeringens oprindelige fleksibiliseringsudspil fra 2012 (Regeringen, 2012). For at beskrive den transformationsproces, som universiteterne aktuelt befinder sig i, vil jeg endvidere inddrage egen tidligere forskning (Sarauw, 2011), der viser, hvordan de seneste ti års reformer på mange måder allerede har banet vejen for de forandringer, som nu er på vej.

\section{Artiklens optikker og læringssyn}

Den reformhistorie, jeg diskuterer i artiklen, er altså en endnu ikke virkeliggjort historie om de mulige konsekvenser af den kombinerede fremdriftsorientering og fleksibilisering. Mine analyser er ikke foretaget på baggrund af et bestemt læringssyn, hvorfra jeg sætter mig til dommer over, hvorvidt den kommende udvikling er hensigtsmæssig eller ej. Ved at bruge historien - og med konkret tilbageblik på de seneste ti års kompetencereformer - er mit anliggende først og fremmest at synliggøre, hvordan kombinationen af fremdrift og fleksibilisering kan ses som en styringsteknologi, der kan være med til at fremme bestemte progressions- og navigationsmønstre blandt de studerende.

Min tilgang kan betegnes som en poststrukturalistisk inspireret policyanalyse ( $\mathrm{fx}$ Foucault 1982; 1996; Dean, 1994; Rose, 1998; Wright \& Shore, 2011). Med betegnelsen poststrukturalistisk mener jeg, at jeg ser de studerendes navigationsmønstre som symptom på nogle socialt forhandlede idealer og problemkonstruktioner - ikke deres kilde. De policyanalytiske aspekter handler i den henseende om, hvordan kombinationen af fremdrift og fleksibilisering i egenskab af de i fremtiden dominerende uddannelsespolitiske styringsrationaler (policies) kan ses som medkonstituerende for disse. 


\section{Reformtendenser mødes}

Fremdrift (i betydningen hastighed) og fleksibilisering (i betydningen et rummeligt uddannelsessystem med plads til diversitet og individuelt tilrettelagte uddannelsesforløb) kan umiddelbart fremstå som hinandens modsætninger. Min påstand her i artiklen er imidlertid, at de to også kan ses som to sider af en styringsambition, der handler om at få de studerende hurtigere igennem. Men hvor førstnævnte virker gennem en ydre tidsstyring, virker sidstnævnte i højere grad ved individualisering af ansvar.

Min bestemmelse af fremdrift og fleksibilsering som to sider af samme styringsambition skal ses i lyset af den historiske transformationsproces, som de videregående uddannelser de seneste ti år har befundet sig i. Derfor vil jeg på de følgende sider kort redegøre for hovedtrækkene i denne proces forstået som en transformation væk fra et erkendelses- og indholdsorienteret regime, hvor idealet for uddannelsesprogression blev set som en fortløbende fordybelse i et bestemt fagligt område, over et lineært-alignet kompetenceregime, hvor uddannelsesudviklingen blev orienteret mod konkrete jobs, til et fremdriftsorienteret regime, som har fokus på de studerendes gennemførelseshastighed, men som samtidig overlejres af et fleksibiliseret kompetenceregime, hvor individuelle præferencer både skal optimere gennemførelsen og sikre en fleksibel og fortløbende tilpasning til arbejdsmarkedet.

Som jeg snart skal uddybe, taler jeg imidlertid ikke om en transformationsproces, hvor de nævnte tendenser successivt afløser eller afvikler hinanden over tid. Som jeg vil vende tilbage til senere, er der i høj grad tale om en proces, hvor forskellige strukturændringer gradvist har banet vejen for de aktuelle tiltag. Det forholder sig derfor snarere sådan, at de nævnte tendenser aktuelt står som konkurrerende og i hinanden indvævede styringsteknologier, der kæmper om politikeres såvel som studerendes gunst.

\section{Det lineært-alignede kompetenceregime (2003 og fremefter)}

En fleksibilisering af de videregående uddannelser kan i en isoleret dansk kontekst ses som et længe ventet skridt frem mod realiseringen af de oprindelige visioner $\mathrm{i}$ den europæiske Bolognaproces (1999) om at øge studentermobiliteten på tværs af institutioner og landegrænser. Selvom der i dag langt fra er fri mobilitet mellem de danske uddannelser og uddannelsesinstitutioner, har de senere års reformer langt hen ad vejen allerede skabt en strukturel infrastruktur for det. I lyset af studiefremdriftsreformen er spørgsmålet imidlertid, om det i grunden er et ønske om at øge studentermobiliteten, der er det primære mål med den kommende fleksibilisering?

I kraft af Danmarks deltagelse i Bolognaprocessen har alle uddannelser allerede i en årrække været omstruktureret i skarpt afgrænsede moduler, som opregnes kvantitativt ved hjælp af ECTS-point og generiske kompetencebeskrivelser, der frem for en 
given fagviden fokuserer på de studerendes læringsudbytte, beskrevet i form af aktive handlekompetencer. Vi har således allerede en gangbar måleenhed for meritering, der vil kunne fungere på tværs af forskellige faglige og institutionelle sammenhænge. Som jeg vil udfolde i det følgende, er den ECTS- og kompetencebaserede måleenhed dog langt fra værdineutral. Tværtimod har den - stik mod den internationale fleksibiliseringsambition - $\mathrm{i}$ en dansk sammenhæng hidtil været brugt som redskab til at styre de studerendes uddannelsesprogression frem mod på forhånd definerede arbejdsmarkedsmål.

Da daværende videnskabsminister Helge Sander i 2003 introducerede de kompetenceorienterede reformer, som skulle sikre Danmarks deltagelse i Bolognaprocessen, var det nemlig med det primære mål for øje at styrke uddannelsernes arbejdsmarkedsrelevans. Således vedtog man bl.a., at der for den enkelte uddannelse skulle formuleres en arbejdsmarkedsrelevant kompetenceprofil, som så skulle tjene som pejlemærke for fastsættelsen af konkrete kompetencemål for enkelte moduler.

De kompetenceorienterede reformer (2003 og fremefter) har i den henseende ikke betydet, at tidligere tiders ambition om at styre de studerendes uddannelsesprogression i en bestemt retning er blevet afviklet. De har snarere betydet, at uddannelsesudviklingen har flyttet sig fra et (idealistisk) erkendelses- og indholdsorienteret til et (konstruktivistisk) handlingskompetence- og joborienteret omdrejningspunkt. Konkret har det på den ene side medført en øget detailstyring af uddannelsesprogressionen som en lineær bevægelse frem mod konkrete jobs, som står i delvis modsætning til den aktuelle fleksibiliseringsdagsorden. ${ }^{1}$ Men i kraft af kompetenceretorikkens generiske og arbejdsmarkedsorienterede karakter er studieordningerne på den anden side kommet til at ligne hinanden mere på tværs af institutioner og fagligheder. Trods den i første omgang lineære alignment og progression mod bestemte arbejdsmarkedsmål, kan man derfor samtidig se de kompetenceorienterede reformer som en grundsten i - og væsentlig forudsætning for - en fleksibilisering, hvor generiske kompetencer anvendes som regneenhed for merit på tværs af uddannelser og fag.

\section{Det fremdriftsorienterede regime (2014 og fremefter)}

I forhold til det lineært-alignede kompetenceregime kan man først og fremmest se den aktuelle fremdriftsreform som en styring på tid, der tvinger de studerende til at studere på fuld tid og/eller tvinger uddannelserne til at indlejre nogle af de sideakti-

\footnotetext{
${ }^{1}$ Som jeg viser i min afhandling, forekommer synet på de studerendes progression som en styringsproblematik, som uddannelserne - ikke de studerende - har ansvar for, intensiveret gennem de senere års reformer. Dette forhold reflekteres i de politiske rammedokumenter såvel som sammenligninger af uddannelsernes studieordninger fra hhv. før og efter kravet om kompetencebasering, som kom i 2003. Mine konklusioner vedr. studieordningerne bygger på analyser af uddannelsesudviklingen fra 1998 til 2011 på ti forskellige humaniorauddannelser ved fem danske universiteter (Sarauw, 2011).
} 
viteter, som de studerende tidligere har forlænget studierne med, som legitime, meritgivende studieelementer.

Fortalere og kritikere diskuterer således reformen som en henholdsvis positiv og negativ intensivering af den øgede detailstyring, som blev igangsat med de kompetenceorienterede reformer (2003f). Forligspartnernes argumenter for reformen er, at studierne bliver mere intensive, kandidaterne kommer hurtigere ud på arbejdsmarkedet, og at flere fuldtidsstuderende vil højne kvaliteten og gavne studiemiljøet. Flere ser desuden den øgede styring - også omtalt som 'skolegørelse' og 'pædagogisering' - som en nødvendighed for at bevare uddannelseskvaliteten på et moderne masseuniversitet med et stort antal førstegenerationsstuderende.

Kritikerne mener omvendt, at reformen rummer en social slagside. De argumenterer blandt andet for, at der fremover vil være mindre plads til at træffe forkerte valg eller dumpe uden efterfølgende at skulle speede yderligere op. Flere påpeger desuden, at der fremover vil være mindre tid og frihed til selvvalgt fordybelse, kreativitetsfremmende og udviklingsorienterede aktiviteter, som allerede er fastlagt i studieordningen, hvorfor reformen sandsynligvis vil resultere i mindre selvstændige og arbejdsmarkedsparate kandidater.

Sidstnævnte har de studerende under det lineært-alignede kompetenceregime i vid udstrækning selv søgt at kompensere for gennem såkaldt studietidsforlængende aktiviteter. I følge en større undersøgelse fra Akademikernes Centralorganisation (AC, 2010) er årsagen til de relativt lange, danske studietider nemlig, at mange studerende ved danske universiteter frem til i dag har sigtet mod en dobbeltkvalificering, der både giver plads til faglige dybdeperspektiver ( $\mathrm{fx}$ gennem udskydelse af eksaminer, ikke meritgivende aktiviteter og udlandsophold) og arbejdsmarkedsrelevante kompetencemål (fx praktik, studiejob, frivilligt arbejde m.m.), hvilket studiefremdriftsreformen efter alt at dømme vil sætte en endelig stopper for.

\section{Det fleksibiliserede kompetenceregime}

Når Bolognaprocessens oprindelige fleksibiliseringsdagsorden endnu ikke har vundet strukturelt indpas i Danmark, skyldes det blandt andet en længerevarende tradition for, at man som studerende ved et dansk universitet gennemfører størstedelen af sine eksaminer ved den samme uddannelse, hvor der typisk er forskellige forskrifter for modulernes rækkefølge samt relativt skrappe indgangskrav for udefra kommende.

I regeringens oprindelige fleksibiliseringsudspil fra 2012 kritiseres dette system imidlertid for at være præget af "uhensigtsmæssige barrierer og blindgyder" samt "unødigt tidsforbrug og dobbeltuddannelse" (Regeringen, 2012, s. 13). Som bod herpå skal den forestående fleksibilisering derfor ifølge regeringens egne formuleringer 
gøre det "muligt for den enkelte at udnytte sit potentiale uden at møde uhensigtsmæssige barrierer og blindgyder" (Regeringen, 2012, s.13) og give de studerende mulighed for "i større udstrækning individuelt \{at\} kunne sammensætte deres egen uddannelse på en måde, så de skærper deres beskæftigelsesmuligheder" (ibid., s. 15).

Det interessante ved regeringens formuleringer (op. cit.) er blandt andet, at de frie valgmuligheder italesættes som et virksomt middel til dels at accelerere gennemførelsen, dels at sikre en fleksibel og fortløbende tilpasning til arbejdsmarkedet. Til forskel fra det lineært-alignede kompetenceregime, vi har i dag, er forventningen tilsyneladende, at man som studerende fremover selv vil kunne gennemskue konsekvenserne af sine uddannelsesvalg og selv sammenstykke en relevant og sammenhængende kompetenceprofil på kryds og tværs af forskellige institutioner og uddannelser. Parallelt med den øgede tidsstyring, som følger med de nye fremdriftskrav, kan man således sige, at fleksibiliseringen hermed introducerer en historisk ny individualisering af ansvaret for egen uddannelsesprogression såvel som efterfølgende beskæftigelse.

De citerede formuleringer (op. cit.) om gevinsterne ved en fleksibilisering af det videregående uddannelsessystem stammer fra regeringens oprindelige fleksibiliseringsudspil fra 2012. Udspillet argumenterer i tråd med de oprindelige visioner for Bolognaprocessen for et radikalt fleksibiliseret kompetenceregime, hvor uddannelsesprogression forstås som en individuelt bundet proces, der er horisontalt orienteret mod indsamling af (et i princippet uafgrænset felt af) generiske kompetencer, som kan omsættes i en hvilken som helst faglig og/eller arbejdsmarkedsmæssig sammenhæng.

I den internationale forskningslitteratur er fordele og ulemper ved en sådan fleksibilisering længe blevet diskuteret og omsat til forskellige diskursive realiteter ( $\mathrm{fx}$ Betts og Smith, 1998; Bridges, 2000; Jenkins \& Walker, 1994; Naidoo og Jamieson 2006; Nixon, Scullion \& Molesworth; 2011). ${ }^{2}$ Fortalerne argumenterer for, at den øgede valgfrihed er en måde at myndiggøre de studerende på, fordi valgfriheden vil gøre dem mere ansvarlige og motiverede for egen læring. De fremhæver bl.a., at de studerende hermed også vil få værdifulde kompetencer i at tilrettelægge og planlægge egen tid og arbejde, hvilket vil højne gennemførelsen og gøre de studerende mere arbejdsmarkedsparate. De mener desuden, at valgfriheden vil gøre universiteterne mere lydhøre over for de studerendes ønsker, hvilket vil gavne uddannelsesudviklingen, skabe større diversitet og optimere informationen om de enkelte kurser, så de studerende får et mere oplyst grundlag for deres valg.

\footnotetext{
${ }^{2}$ Flere af disse kilder diskuterer både for og imod fleksibilisering, hvorfor en egentlig opdeling i fortalere og modstandere ikke er mulig og/eller rimelig.
} 
Kritikerne mener heroverfor, at fleksibilisering fører til fragmentering af viden, overfladelæring, dårligt sammenhængende progression mellem moduler samt manglende tilhørsforhold til studiested og fagfællesskab. De mener, at den rummer en potentiel nedprioritering af de langsigtede faglige og/eller arbejdsmarkedsmæssige mål samt en medfølgende risiko for, at de enkelte moduler i stigende grad vil udvikle sig ud fra (måske kortsigtede) studenterinteresser. Et kerneargument er her, at den øgede valgfrihed medfører en forbrugergørelse af de studerende, som betyder, at de i stigende grad ser deres uddannelse som en vare, de vælger blandt mange andre. Dvs. uden dybere eksistentiel forpligtelse, deltagelse og engagement, hvilket ifølge kritikerne giver incitament til en passiv, instrumentel læringstilgang.

Som jeg vil uddybe i det følgende, tyder meget imidlertid på, at den radikale fleksibilisering, som lå i det oprindelige regeringsudspil, og som debatteres i den internationale forskning, ikke vil være fuldt kommensurabel med de aktuelle, danske fremdriftskrav.

\section{To sider af samme styringsambition?}

I løbet af efteråret 2013 har jeg interviewet en række studerende om deres syn på studiefremdriftsreformen. ${ }^{3}$ Mange taler på den ene side varmt for en yderligere fleksibilisering, da de mener, en sådan falder fint i tråd med deres ønsker om at bo i et rummeligt samfund, hvor der er plads til at fejle og forfølge egne interesser og mål. Men flere udpeger på den anden side netop samme rummelighed som den samfundsmæssige pris, vi betaler, for de skærpede fremdriftskrav. De studerende spidsformulerer hermed et umiddelbart modsætningsforhold mellem fremdrift og fleksibilisering og rejser samtidig spørgsmålet om, hvordan de to teknologier i grunden vil forholde sig til hinanden som dele af samme uddannelsesregime?

Tilbage i 2005 forudså uddannelsesprofessor Jens Rasmussen, at en dansk realisering af Bolognaprocessens fleksibiliseringsvision sandsynligvis ville resultere i en gennemgribende fragmentering af uddannelsesprogressionen (Rasmussen, 2005). Spørgsmålet er fremdeles, om kombinationen af fremdrift og fleksibilisering vil bringe os i en situation, hvor ingen - ud over den enkelte studerende - tager ansvar for, hvordan uddannelserne som helhed hænger sammen?

De politiske fremdriftskrav kalder på den ene side umiddelbart på en yderligere detailstyring af uddannelserne med færre valgmuligheder og mere ensretning. Det ligger således lige for, at både institutioner og studerende vil have interesse $i$, at der

\footnotetext{
${ }^{3}$ Interviewmaterialet omfatter fokusgruppeinterview med hhv. studiestartere og deltagere på næstenkandidatkurser ved Københavns Universitet samt under de studerendes protestaktioner mod fremdriftsreformen. Sidstnævnte skønnes at udgøre en mindre gruppe på omkring ti procent af de studerende, som på forhånd må tilskrives en vis skepsis.
} 
tilbydes uddannelser, der hænger sammen på langs i lineære forløb med en på forhånd fastlagt progression og langt mere undervisning end i dag, så de studerende kan nå at gennemføre dem. Ser man på de nye fremdriftskrav alene, kan man altså umiddelbart forvente en yderligere skærpelse af den lineært-alignede forløbsorientering, vi kender fra det nuværende kompetenceregime.

Men den øgede ansvarliggørelse af den enkelte i forhold til at navigere målrettet og ikke 'fjumre', vælge forkert, dumpe eller af andre årsager forsinke sig rummer på den anden side også en modsatrettet sandsynlighed. For det ligger umiddelbart også lige for, at den enkelte - frem for at følge færdigpakkede forløb - i stigende grad vil søge en kombination af moduler, der er 'STÅ-sikre', eksempelvis fordi de matcher kompetencer, som hun eller han i forvejen besidder. Som jeg vil vende tilbage til i det følgende afsnit om fleksibilisering og fremdrift som en målrettet opportunisme, kan den sideløbende individualisering af ansvaret for egen progression og beskæftigelse samtidig medføre, at et stadigt stigende antal studerende søger at sikre sig en unik kompetenceprofil ved at kombinere moduler fra forskellige uddannelser og fag.

Alt afhængig af, hvor fleksible kombinationsmulighederne reelt bliver, kan den kombinerede fremdriftsorientering og fleksibilisering derfor også resultere i et regime i stil med det, Jens Rasmussen forudså, hvor konkurrencen i høj grad kommer til at stå mellem enkeltstående uddannelsesmoduler, og hvor de langsigtede pejlemærker for progressionen, som i dag er givet ved en hel bachelor- eller kandidatgrad, gennemført ved samme uddannelse, enten nedtones eller helt falder bort.

\section{Diskussion: Fleksibilisering, fremdrift og målrettet opportunisme}

Med tilbageblik på de seneste års reformer har jeg ind til nu beskrevet den transformation, som de videregående uddannelser aktuelt befinder sig i, som en transformation fra et lineært-alignet kompetenceregime til et fremdriftsorienteret regime, der overlejres af - og måske står i delvist konkurrence med - et nyt og fleksibiliseret kompetenceregime. Som illustreret i figuren nedenfor, taler jeg ikke om regimer, der successivt afvikler hinanden over tid. Det primære interventionsmål er i alle tre tilfælde arbejdsmarkedsorientering, hvortil fremdriftsorientering og fleksibilisering, hver for sig føjer en ny styringsteknologi i form af hhv. tidsstyring og individualisering. 


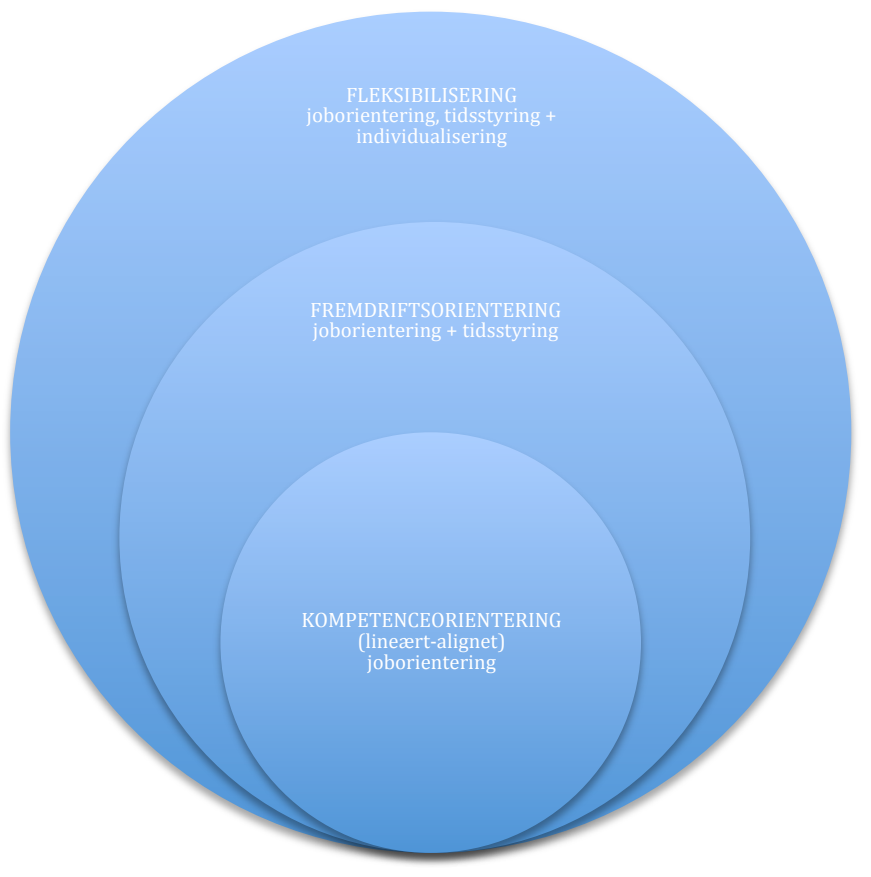

Figur 1: Figuren illustrerer, hvordan kompetenceorientering, fremdriftsorientering og fleksibilisering ikke skal ses som modsatrettede tendenser eller regimer, der successivt afvikler hinanden over tid. Som der ses, er det primære mål $i$ alle tre tilfælde arbejdsmarkedsorientering, hvortil fremdriftsorientering føjer en ny tidsstyring, mens fleksibiliseringen indebærer en individualisering af ansvaret. Figuren er forfatters egen illustration.

Der er i skrivende stund stadig nogen usikkerhed om den konkrete udmøntning af studiefremdriftsreformen. Usikkert er derfor også, hvordan konkurrenceforholdet mellem kompetenceorientering (beskæftigelse), fremdrift (tidsstyring) og fleksibilisering (individualisering) reelt vil tage sig ud i de studerendes bevidsthed og som baggrund for deres til-, fra- og omvalg, mens de er i uddannelse.

Jeg vil imidlertid gerne fastholde min indledende påstand om, at den fremdriftsorienterede tidsstyring og fleksibiliserede individualisering kan ses som to sider af én og samme styringsambition, som handler om at få de studerende hurtigere igennem og ud på arbejdsmarkedet. I sammenhæng med det øgede pres om hurtig og effektiv gennemførelse, bliver fleksibilseringen nemlig reduceret fra den idealforestilling om frihed til at forfølge egne interesser, som de studerende i mine interview argumenterede for, til udelukkende at omhandle frihed til at vælge den hurtigste og mest effektive vej gennem systemet og ud. Eller anderledes sagt: Frihed til at meritere eventuelle omvalg og hhv. til- og fravælge fag og moduler efter egne styrkepositioner med det primære formål at undgå forsinkelser.

En klar forskel fra tidligere er efter min opfattelse, at den kombinerede fremdrift og fleksibilisering hermed lægger op til en intensiveret selvovervågning og selvkorrektion hos de studerende, der som noget nyt gives incitament til bestandigt at scanne egen kompetenceprofil i strategisk relation til andre mulige moduludbud, som fore- 
kommer mere formålstjenlige i betydningen af den lettest farbare vej gennem systemet. I modsætning til velfærdsstatens eksistentielle persontype, der ifølge økonomiprofessor Ove Kaj Pedersen (Pedersen, 2011) vedholdende ville kæmpe for at tilegne sig stoffet (i den tro, at det var en del af en meningsfuld helhed, som måske først vil vise sig på længere sigt), kan man nemlig sige, at den kombinerede fremdrift og fleksibilisering tildeler de studerende et helt nyt ansvar for hurtigst muligt selv at flytte sig et andet sted hen, hvis de er utilfredse med situationen. Sat på spidsen kan den kombinerede fremdrift og fleksibilisering derfor vel tænkes også at blive medkonstituerende for en opportunistisk persontype, der udelukkende navigerer efter umiddelbart materialisérbare incitamenter ( $\mathrm{fx}$ givet ved kompetencemålene for de enkelte moduler). ${ }^{4}$

\section{Konklusion}

Med tilbageblik på de seneste ti års videregående uddannelsesreformer har jeg her påpeget, hvordan en fleksibilisering isoleret set kan ses som en realisering af Bolognaprocessens oprindelige vision om at øge studentermobiliteten. Set i lyset af den aktuelle fremdriftsreform er det imidlertid tvivlsomt, hvorvidt en øget studentermobilitet kan forstås som et mål i sig selv. Som jeg har foreslået, må fleksibilisering i nærværende sammenhæng snarere ses som en styringsteknologi, der skal understøtte de politiske fremdriftsvisioner om at få de studerende hurtigere igennem systemet og ud på arbejdsmarkedet. Dét ses blandt andet ved, at ansvaret for rettidig gennemførelse, progression og arbejdsmarkedsrelevans flyttes over på den enkelte studerende, alt imens hun samtidig får færre muligheder for at fejle og/eller vælge om undervejs.

Ethvert forsøg på at fremskrive resultatet afhænger af politisk ståsted og læringssyn. Det kan således både have form af mere motiverede studerende, hurtigere gennemførelse og/eller fragmenteret læring og opportune valg. At nogen - ud over den enkelte studerende - tager ansvaret, forekommer dog i begge tilfælde påkrævet.

Laura Louise Sarauw (f. 1977) er i dag ansat som postdoc ved Institut for Uddannelse og Pædagogik på Aarhus Universitet. Tidligere har hun blandt andet arbejdet som kursusleder for universitetspædagogikum ved Det Humanistiske Fakultet, Københavns Universitet, og skrevet ph.d. ved Afdeling for Pædagogik, ligeledes Københavns Universitet, om den danske fortolkning af Bolognaprocessen og ud-

\footnotetext{
${ }^{4}$ Pedersen (2011) beskriver velfærdsstatens uddannelsesideal som 'den eksistentielle person', der var drevet af søgen efter mening og erkendelse. Heroverfor betegner nutidens konkurrencestatsdiskurs er konstituerende for 'den opportunistiske person', som er drevet af incitamenter og udelukkende indgår i relationer med henblik på nyttemaksimering. Kendetegnende for den opportunistiske personlighedstype er således, at hun ikke har noget selvstændigt eksistentielt projekt med sin uddannelse og/eller tilværelse. For hende er bestandig personlig fleksibilitet derimod en pragmatisk nødvendighed for at klare sig i en omverden, hvis forandringshast er accelereret.
} 


\section{Litteratur}

Akademikernes Centralorganisation (2011). Det frie valg eller det frie fald? Overgangen fra studium til job. Kbh.: AC 2012, online: http://www.ac.dk/media/99390/det_frie_valg.pdf

Andersen, H. Leth \& Bager, L. T. (2012). Alignment - mål og motivation i de videregående uddannelser. In: Leth Andersen \& Jacobsen (red.), Udannelseskvalitet $i$ en globaliseret verden. Vidensøkonomiens indtog i de videregående uddannelser. Kbh.: Gyldendal, s. 119-133.

Bridges, D. (2000). Back to the future: The higher education curriculum in the 21st century. Cambridge Journal of Education, 30(1), 37-55.

Folketinget (2013). Lov om ændring af universitetsloven, lov om erhvervsakademiuddannelser og professionsbacheloruddannelser, lov om videregående kunstneriske uddannelsesinstitutioner, lov om maritime uddannelser og lov om statens voksenuddannelsesstøtte (SVU), Vedtaget af Folketinget ved 3. behandling den 28. juni 2013, Folketinget: Retsinformation, 2013, online: https://www.retsinformation.dk/Forms/R0710.aspx?id=152698

Foucault, M. (1982). The subject and power. In: Dreyfus \& Rabinow (Eds.), Michel Foucault: Beyond structuralism and hermeneutics. Chicago: The University of Chicago Press.

Foucault, M. (1994). Governmentality. In: J. D. Faubion (Ed.), Power: Essential works of Michel Foucault, vol. 3. London: Penguin, 1994.

Jenkins, A. \& Walker, L. (Eds.) (1994). Developing student capability through modular courses. London: Kogan Page, 1994.

Naidoo, R. \& Jamieson, I. (2006). Empowering participants or corroding learning? Towards a research agenda on the impact of student consumerism in higher education. In: H. Lauder, P. Brown, J. Dillabough \& A. H. Halsey (Eds.): Education, globalization and social change (s. 875-884). Oxford: Oxford University Press.

Nielsen, G. B. (2010). Student figures in friction. Explorations into Danish university reform and shifting forms of student participation. PhD Thesis, Danish School of Education, Aarhus University.

Nielsen, G. B. (2011). Timing student's freedom: On paradoxes of accountability and efficiency. In: J. E. Kristensen, H. Nørklit \& M. Raffnsøe-Møller (red.), University performance management at Danish universities (175-193). København: DJØF Publishing, Jurist og Økonomforbundets forlag.

Nielsen, G. B. og Sarauw, L. L. (2012). Globalisering som spørgsmål - modulisering som svar. In: Leth Andersen \& Jacobsen (red.): Udannelseskvalitet $i$ en globaliseret verden - Vidensøkonomiens indtog $i$ de videregående uddannelser (101-118). Kbh.: Gyldendal.

Rasmussen, J. (2005). Progression i professions- og universitetsuddannelser. Asterisk, nr. 22(2005), 21-22. 
Nixon, E., Scullion, R. \& Molesworth, M. (2011). How choice in higher education can create conservative learners. In: M. Molesworth, R. Scullion \& E. Nixon (Eds.): The marketisation of higher education and the student as consumer, (196-208). London and New York: Routledge.

Pedersen, O. K. (2011). Konkurrencestaten. Kbh.: Hans Reitzels Forlag.

Regeringen (2012). Redegørelse om større sammenhæng $i$ det videregående uddannelsessystem, den 13. April 2012, online:

http://www.ftf.dk/fileadmin/Bruger_filbibliotek/Uddannelse_og_ledelse/Redeg oerelse_om_stoerre_sammenhaeng_PDF.pdf

Rose, N. (1989). Governing the soul: The shaping of the private self. London: Free Association Books.

Wright, S. \& Shore, C. (2011). Conceptualising policy; Technologies of governance and the politics of visibility. In: C. Shore, S. Wright \& D. Però (Eds.): Policy worlds. Anthropology and the analysis of contemporary power (3-25). EASA Series. Oxford: Berghahn.

VTU (2003). Mod en dansk kvalifikationsnøgle for videregående uddannelser ("Qualifications Framework"). Endelig rapport. Tiltrådt af Bologna følgegruppen 15. januar 2003. Kbh.: VTU. 